\title{
The Effects of Genders of Prospective Teachers on their Attitudes towards Teaching Profession: A Meta-Analysis
}

\author{
Ümit Polat ${ }^{1 *}$
}

\author{
${ }^{1}$ Niğde Ömer Halisdemir University, Niğde, TURKEY
}

*Corresponding Author: polatumit58@hotmail.com

Citation: Polat, Ü. (2019). The Effects of Genders of Prospective Teachers on their Attitudes towards Teaching Profession: A Meta-Analysis. Pedagogical Research, 4(1), em0027. https://doi.org/10.29333/pr/5732

Published: March 12, 2019

\begin{abstract}
One of the factors supporting the professional success of prospective teachers is their attitudes towards teaching profession. Many studies have been carried out on determining the attitudes of prospective teachers towards teaching profession. One of the main questions in those studies is to determine if the gender is effective or not. In this study, the meta-analysis was performed in order to determine the effects of gender on the attitudes of prospective teachers towards teaching profession between 2010 and 2015. As a result of database scanning, it has been seen that there were 34 publications that contain related data for metaanalysis. According to the performed analyses, it was concluded that there was no publication bias and it was required to perform analysis according to random effects model. According to meta-analysis results, the general impact level of the publications was 0.323 and they were at small size level. In other words, attitudes of female students towards teaching profession were higher than that of male students. According to the analyses from the aspect of score type of the departments, at which the prospective teachers were studying, it can be said that the differentiation by scores was significant and the attitudes of female and male students were similar in science-math scores. In analyses performed from the aspect of geographical regions of study, it was concluded that the differentiation was not significant.
\end{abstract}

Keywords: prospective teacher, attitudes towards teaching profession, meta-analysis gender

\section{INTRODUCTION}

With the increase in social expectations, there is more expectation about the quality of educational outcomes. The important factors that determine the quality of the outputs of the education are the learning-teaching process, the quality of the students and the quality of the teacher. It is undeniable fact that the teachers have effect on the quality of the educational outputs. The training of qualified teachers is one of priorities related educational for almost all countries (Furlong et al., 2009, p. 1).

One of the important factors affecting the success of teachers is their attitude towards the profession. The attitudes of the teachers affect the pleasure they receive from the profession, the dedication to the profession, the belief that the teaching is necessary and important, and the belief in the development of the profession (Güneyli and Aslan, 2009). If the prospective teachers have a positive attitude towards the profession, they can easily develop the internal motivation about teaching to their students in the future, communicate effectively with the students and spend more on individualizing and diversifying their learning situations (Andronache et al., 2014).

Authors such as McGuire (1989) and Wood (2000) argue that the attitude is formed in three dimensions; mental, affective and behavioral. Mental dimension; the perceptions, beliefs, and assumptions of personal facts and events. Emotional reactions and affective experiences of individuals and phenomena constitute the affective dimension. 
The behavioral dimension is based on the estimation and inference of the way in which it interacts with facts or facts based on assumptions and beliefs (cited in Andronache et al., 2014).

The professional perceptions of the pre-service teachers about their values and attitudes, in other words, the way they perceive the profession are necessary, at least as much as the information. Teachers' attitudes towards the profession are concepts that are not clearly expressed and are shaped by the subjects taught in teaching, student, classroom environment and in general without being aware of them. These concepts significantly affect teachers' thinking processes, classroom activities, professional changes, improvements and teaching skills (Güneyli and Aslan, 2009).

The thoughts, attitudes, and priorities of pre-service teachers about the teaching profession will be effective in defeating the problems they face while continuing the profession and continuing studies. Teacher training programs have a great role in the development of the opinions of the candidates against the teaching profession.

Researches on the attitudes of prospective teachers;

a) The effect of the gender factor

b) The type of program they are continuing

c) University entrance points

d) Whether she/he is a teacher in her family

e) Many variables such as class levels are examined.

Some of the studies in the literature can be summarized as follows:

As a result of the research conducted by İpek et al. (2015), it was observed that the attitudes of female prospective teacher towards the teaching profession were higher than male prospective teacher. As a result of the research; It was found that the positive attitude scores of the prospective teachers who were studying in the second year were higher than the fourth-grade the prospective teachers.

Altunkeser (2014) in his thesis on elementary school prospective teachers, it was found that university acceptance exam score and academic achievement are significant predictors of the attitude towards teaching profession. It was concluded that there was no significant difference between the attitudes of the prospective teachers towards the teaching profession and their gender, and there was no significant difference between the attitude towards the teaching profession and the high school graduated.

In another study, according to the mean score of the general scale, it was observed that the prospective teachers in the study group had a positive attitude towards the teaching profession in general and that the female prospective teachers' attitudes towards the teaching profession were more positive than the male. Although there was no significant relationship between the family income status and the attitudes of the prospective teachers who participated in the study, it is understood that the participants from the low-income and middle-income group have a more positive attitude towards the profession than the participants from the upper-income group (Karatekin et al., 2015).

In a study on prospective primary mathematics teacher candidates; it is observed that the students' attitude towards teaching profession is moderate level. Generally it is accepted "appropriate" level and positive for attitude towards teaching profession. Again, it was determined that there was no statistically significant difference between students' attitudes towards teaching profession according to gender variable. There is no statistically significant difference between the attitude points related to the teaching profession according to the graduated high school and the grade level of the students (Taşdemir, 2014).

According to the results of a study conducted on the 4th-grade prospective teacher of Muş University education faculty, it was found out that the prospective teachers' attitudes towards the teaching profession were highly positive. It has been concluded that the relationship between prospective teachers' attitudes towards the teaching profession and the departments they are studying is significant. However, the prospective teachers' attitude does not differ according to their gender (Kesen and Polat, 2014).

In the study conducted on the attitudes and concerns of the students of Trakya University CEIT department, it was revealed that their attitudes towards the profession were positive and above moderate level. It was concluded that the gender of prospective teachers did not have an impact on the attitudes towards the teaching profession but have an effect on their anxiety. It was determined that there was no differentiation according to class level and whether there was a teacher in their family (Akgün and Özgür, 2014).

In the study conducted on Sakarya University Faculty of Education Preschool Education program, it was found that gender and class variables did not create a significant difference on the attitudes of prospective teachers towards teaching profession and communication skills (Tunçeli, 2013).

According to the longitudinal study on the attitudes of prospective physics teachers towards the teaching profession, although there were no differences according to gender in the first measurements, it was determined that there was differentiation in favor of girls in the second measurements (Tanel and Tanel, 2013).

According to the study of the attitude of the first-year students of the Faculty of Education of Sakarya University towards the teaching profession, it was determined that there was a significant difference between the 
prospective teachers' attitudes in the girls' favor. In addition, differentiation was determined according to the programs; Computer Education and Instructional Technology Education, Science Education, Elementary Mathematics Education. It was concluded that the opinions of the students studying in Primary School Teaching, Social Studies Education, and Preschool Education diverged from each other (Gür Erdoğan and Zafer Güneş, 2012).

In the study on the attitudes of the first and fourth grade pre-service teachers studying at Uludağ University towards the teaching profession, it was determined that there was no difference according to the grade level and graduation type of high school. However, it is concluded that there is a difference in favor of girls according to their gender. There was no significant difference between the economic status of teachers' teachers and attitudes towards teaching profession (Gökçe and Sezer, 2012).

Artvin Çoruh University Faculty of Education Department of Primary School Teacher Education in the 1st, 2nd, 3rd and 4th year of the study conducted with a total of 192 university students according to the gender, grade level and graduated from the type of high school teacher candidates determined that there was no significant difference in attitudes. (Açışlı and Kolomuş, 2012).

According to the results of the study conducted on the attitudes of the prospective teachers in the classroom teaching of Cumhuriyet University, it was determined that the prospective teachers' attitudes were moderate and high, and there was a difference in favor of girls. Besides, it was determined that there is differentiation according to grade level but there is no differentiation according to income level (Uğurlu and Polat, 2011).

Gazi, Ahi Evran and Kastamonu University science teachers' attitudes towards teaching profession in the study on the attitudes of prospective teachers were determined to be at a moderate level. According to the analysis made by gender, there was a significant difference in favor of female students. It also varies according to the type of high school graduated. It is observed that the difference is between Anatolian Teacher High School-Anatolian High School (in favor of Anatolian Teacher High School) and Anatolian High School-General high school (in favor of Flat High School) (Pektas and Kamer, 2011).

According to the results of the study on the relationship between the attitudes of education faculty students towards the teaching profession and their anxiety levels, their attitudes were found to be positive, their anxiety levels were low and there was a low negative and significant relationship between attitude and anxiety. It was determined that the gender of the pre-service teachers was effective on the attitudes and that the attitudes of the girls were more positive (Doğan and Çoban, 2009).

According to the results of the study conducted on the attitudes of the teacher candidates studying in Inonu University Faculty of Education towards the teaching profession, it was determined that the attitude of teacher candidates did not change according to the gender and the program they continued (Üstüner et al., 2009).

The attitudes of Turkish teacher candidates studying at the last year of the Turkish Language Teaching Department of the Faculty of Education of Dokuz Eylül University were found to be high. In addition, it was concluded that the attitudes of girls' teachers and those of teachers in their families were higher. However, it is determined that the graduated high school type has no effect on attitude (Çetinkaya, 2009).

In the study conducted on the prospective Turkish teachers studying at the Department of Turkish Language Teaching of Gazi University Faculty of Education, it was determined that the attitudes of the prospective teachers were generally positive, and they liked the profession (Temizkan, 2008).

It has been determined that there are many studies positive and high in evaluating the prospective teachers' attitudes in general (Akpınar et al., 2006; Çetinkaya, 2009; Andronache et al., 2014; Kayan Fadlelmula, 2013; Caglar, 2013; Baykara Pehlivan, 2008; Baykara Pehlivan, 2010; Akbulut and Karakus, 2011). It is seen that high attitudes of prospective teachers will provide professional satisfaction (Taşdemir, 2014) and promising in terms of the teaching profession (Kesen and Polat, 2014). However, it is stated that the prospective teachers' attitudes are low (Kahyaoğlu et al., 2013).

In general, there is a perception that the teaching profession is a suitable profession for women (Yaman et al., 2001; Özyurt and Eren, 2014). The teaching profession is seen as a profession that is suitable for women and a state guaranteed. In addition, although the profession of teaching is seen as a woman profession, the negativity of women in business life is perceived differently by society (Polat et al., 2015). Therefore, in many studies, it was examined whether gender had an effect on attitudes towards teaching. According to the results of the study that the gender is not effective (Haciömeroğlu and Şahin Taşkın, 2010; Can, 2010; Üstüner et al., 2009; Dinçer and Y1lmaz, 2015; İlter and Köksalan, 2011), although there are studies, girls have a more positive attitude. (Akpinar et al., 2006; Cetinkaya, 2009; Capa and Cil, 2000; Duatepe and Akkus-Kapla, 2004; Gurbuz and Kisoglu, 2007; Caglar, 2013; Kiziltas et al., 2012; Güneyli and Aslan, 2009; Gürbüz and Kışoğlu, 2007). In some studies, it was determined that male pre-service teachers have a more positive attitude (Eraslan and Çakıc1, 2011; Çapa and Çil, 2000).

Regarding the programs they are continuing, differentiation is effective according to the programs they study (Şahin Taşkın and Hacıömeroğlu, 2010; Gökçe and Sezer, 2012; Gür Erdoğan and Zafer Güneş, 2012) and Şahin Taşkın, 2010; Üstüner et al., 2009; Bozdoğan et al., 2007). In these studies, it was determined that all of the 
prospective teachers had high attitudes, but the candidates in some programs had higher attitudes. It is not possible to go to any generalization in different programs. Studies on university entrance scores were conducted according to departments rather than studies on score types. When we look at the studies in general, the selected departments of the selected university are the preferred studies (Tümkaya, 2011; Korkmaz and Usta, 2010) and there are studies in which certain groups of students in different universities are preferred (Altunkeser, 2014; Aydın and Sağlam, 2012).

According to the results of some research (Çağlar, 2013; Aydın and Tekneci, 2013; İpek and Camadan, 2012; Tok, 2011), it is determined that the level of the classroom is effective, while there is no differentiation according to the grade level (Gökçe and Sezer, 2012).

In the studies conducted on whether there is a teacher in her family, it is expected that the parents of the teachers will show a more positive attitude towards teaching (Source). There are studies (Aydın and Sağlam, 2012; İlter and Köksalan, 2011).

Studies on whether gender effect differs according to departments could not be reached. In general terms, studies on gender attitudes towards the teaching profession have not been found. Independently, a meta-analysis study is needed to determine the effect of gender on attitudes toward the teaching profession.

\section{META-ANALYSIS}

Meta-analysis is the analysis of the results of many researches in order to integrate the findings (Ellis, 2010, pp. 94-95). Meta-analysis is a technique used to synthesize research (Borenstein et al., 2009; Littell et al., 2008). It is basically a combination of individual research data to find answers to a specific research question (Borenstein, Hedges et al., 2009).

Meta-analysis is generally criticized for the fact that apple and pear cannot be combined, there will be publication bias and a combination of good and bad publications. In the meta-analysis literature, it is emphasized that the answer to criticism is correct if the research question is the counting of the fruits (Üstün and Eryllmaz, 2014; Rosenthal and DiMatteo, 2001).

In order to combine the meta-analysis studies, the effect size is calculated for each study. Effect size is the strength and direction of the relationship between two variables and defines it as currency in a meta-analysis (Borenstein et al., 2009; Littell et al., 2008).

Meta-analysis work has a process to be meticulously followed because it is based on systematic data collection. This process consists of the following stages:

1. Defining dependent and independent variables

2. Systematic collection of primary studies and selection of each study carefully

3. Making the heterogeneity test on the obtained data

4. Calculation of impact sizes and combining studies according to central tendency

5. Determining the level of significance of central tendency, using fixed and random effect models

6. Evaluation of the significance of the average effect size

In Turkey, studies on the attitude of prospective teacher towards the profession of teacher were conducted. One of the main independent variables in this study was to examine whether gender has an effect on attitudes (Üstün and Eryilmaz, 2014; Rosenthal and DiMatteo, 2001).

In this context, the accuracy of the following hypotheses was tested by the meta-analysis method:

1. H0: Girls' attitudes towards teaching profession do not differ according to men.

2. H0: There is no effect on the attitude of gender to teaching according to the entry score types (MatScience, Mat-Turkish, Social Sciences) of the programs where prospective teachers are studying.

3. H0: Gender has no effect on attitudes towards teaching according to geographical regions where the study sample is located.

\section{METHOD}

This study is based on meta-analysis. The meta-analysis study is based on the generalization of quantitative studies.

\section{Data Collecting}

The National Thesis Center, Ulakbim Database, and Scholar Google database were searched for answers to the research question. The screening study was started on November 13, 2015 and the last screening was made on 21 December 2015. The search was made with the keywords "Teacher Candidates" and "Teachers' Attitude". At the end of the study, 58 theses and 258 articles were obtained. Later publications; 


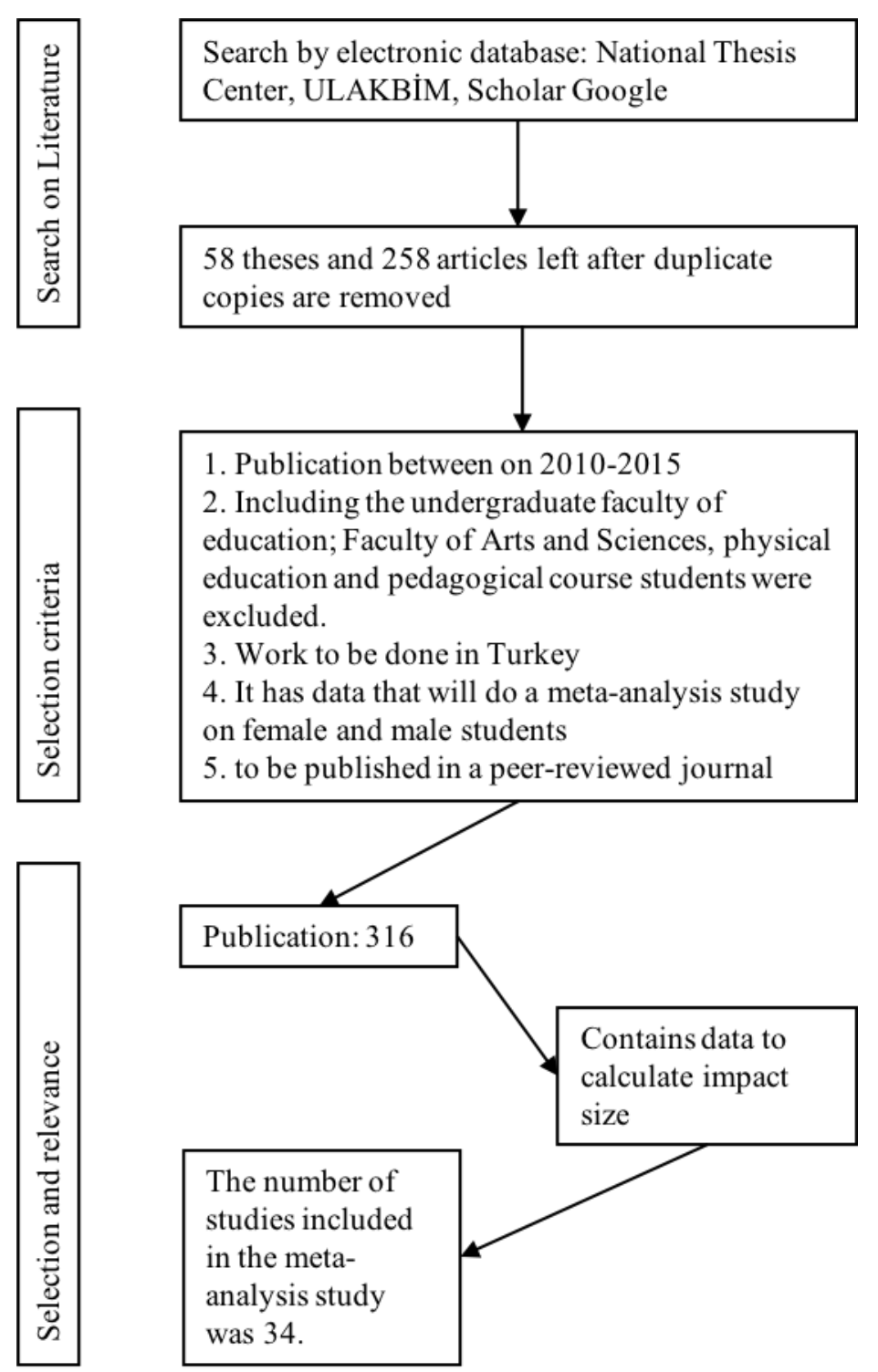

Figure 1. Literature Review and Process of Adding Meta to Analysis

a) The publication date is between 2010-2015

b) The education faculty includes undergraduate students; (Faculty of Arts and Sciences, Department of Physical Education and Pedagogical Courses students are excluded.)

c) to be held in Turkey

d) Publications should have data related to meta-analysis of female and male students

e) To be published in a refereed journal

It was decided that 34 publications were suitable for meta-analysis. The appropriateness of these publications was examined by 2 other researchers.

\section{Data Analysis}

A comprehensive meta-analysis ${ }^{\circledR}$ program was used for effect size. It was decided to use standardized averages due to the use of different measurement tools and different measurement units in the studies. Therefore, Hedges Dis $g$ value was calculated for each study (Rosenthal and DiMatteo, 2001). The reliability value was accepted as 0.05 in the studies.

$$
\text { Hedges's }^{\prime} g=\frac{M_{1}-M_{2}}{S_{\text {pooled }}}
$$

The simplest and most common approach to assess whether there is heterogeneity among studies is the (k-1) chi-square heterogeneity test ( $\mathrm{Q}$ statistic) proposed by Cochran. The heterogeneity test tests the null hypothesis that all studies evaluate the same effect (Higgins et al., 2003).

In combining different effect sizes with meta-analysis; The meta-analysis model to be used is important. At this point, it is possible to talk about two types of meta-analysis models. The first one is the fixed effect model and the 
Table 1. Thalheimer and Cook Effect Size Classification

\begin{tabular}{lll}
\hline Classifications & Min. & Max. \\
\hline Unimportant & $-0,15$ & 0,15 \\
\hline Small & 0,15 & 0,40 \\
\hline Moderate & 0,40 & 0,75 \\
\hline Large & 0,75 & 1,10 \\
\hline Very large & 1,10 & 1,45 \\
\hline Superb & 1,45 & + \\
\hline
\end{tabular}

Funnel Plot of Standard Error by Hedges's g

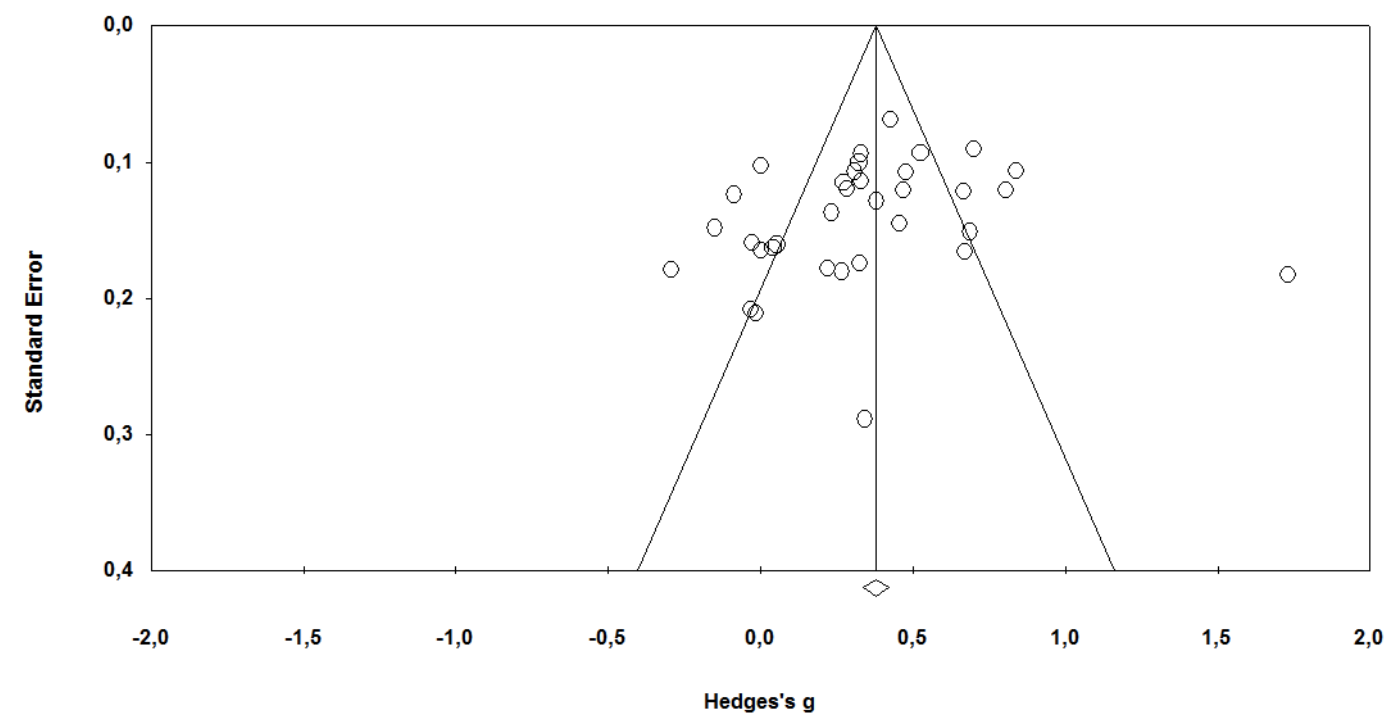

Figure 2. Funnel Plot of Standard Error by Hedges's g

second one is the random effect model. The fixed effect model has the assumption that the universe effect sizes do not change in the studies included in the meta-analysis. Therefore, the standard deviation of the universe effect sizes for all studies is equal to zero. In the random effect model, it is assumed that the universe effect sizes vary from study to study. Hence the standard deviation of universe effect sizes for all studies is different from zero (Ellis, 2010; Borenstein et al., 2009).

\section{Moderator Variable}

The number of student admissions grade for the undergraduate programs of the prospective teachers; there are researches on the effect of gender on students' job choices. In the studies carried out, the programs are differentiated, and it is examined whether there is a moderator effect on the types of score for grouping. As another moderator variable, the geographical region of the researched university was examined.

\section{Effect Size Classification}

Cohen d, whose effect size classification is calculated, relates to the interpretation of Hedges's $g$ values. The more detailed classification (Thalheimer and Cook, 2002) is given in Table 1. (cited in Aydin et al., 2011).

\section{Outliers Analysis and Publication}

The Funnel Diagram (Figure 2) was omitted to determine the bias of the publications included in the study in terms of effect and sample size.

It was partially symmetrical on the basis of the axis according to the effect size and the diagram drawn according to the standard error. Since it is not decided as a whole by looking at the drawn diagram, it should be done in different analyzes. Kendall tau value was calculated for this. The tau value was calculated as $-0,184(\mathrm{z}=1,527 \mathrm{p}=$ 0,127). According to these results, it can be said that there is no publication bias.

\section{FINDINGS}

In the presentation of the findings of the study, firstly, after the descriptive information is presented, metaanalysis findings related to the general impact calculation will be presented. Then, the analyses made according to 
Pedagogical Research, 4(1), em0027

Table 2. Descriptive Distribution of Selected Publications

\begin{tabular}{|c|c|c|}
\hline Moderator Variable & $\mathbf{N}$ & Percentage \\
\hline \multicolumn{3}{|l|}{ Region } \\
\hline Mediterranean & 3 & $8,8 \%$ \\
\hline Eastern Anatolia & 7 & $20,6 \%$ \\
\hline Aegean & 4 & $11,8 \%$ \\
\hline Southeastern Anatolia & 1 & $2,9 \%$ \\
\hline Central Anatolia & 5 & $14,7 \%$ \\
\hline Black Sea & 5 & $14,7 \%$ \\
\hline Marmara & 7 & $20,6 \%$ \\
\hline Mixed & 2 & $5,9 \%$ \\
\hline \multicolumn{3}{|l|}{ Grade } \\
\hline 1- Math-Science & 9 & $26,5 \%$ \\
\hline 2- Social Sciences & 3 & $8,8 \%$ \\
\hline 3- Math- Turkish & 11 & $32,4 \%$ \\
\hline 4- Others & 11 & $32,4 \%$ \\
\hline \multicolumn{3}{|l|}{ Year } \\
\hline 2010 & 9 & $26,5 \%$ \\
\hline 2011 & 6 & $17,6 \%$ \\
\hline 2012 & 6 & $17,6 \%$ \\
\hline 2013 & 6 & $17,6 \%$ \\
\hline 2014 & 4 & $11,8 \%$ \\
\hline 2015 & 3 & $8,8 \%$ \\
\hline
\end{tabular}

Table 3. Distribution of Publications by Thalheimer and Cook Effect Size Classification

\begin{tabular}{lcc}
\hline Classifications & $\mathbf{N}$ & Percentage \\
\hline Unimportant & 9 & $26,5 \%$ \\
\hline Small & 13 & $38,2 \%$ \\
\hline Moderate & 8 & $23,5 \%$ \\
\hline Large & 3 & $8,8 \%$ \\
\hline Very Large & 0 & $0,0 \%$ \\
\hline Superb & 1 & $2,9 \%$ \\
\hline Total & 34 & $100,0 \%$ \\
\hline
\end{tabular}

Table 4. Effect size and homogeneity test by fixed and random effect models

\begin{tabular}{lcccccc}
\hline Model & $\mathbf{n}$ & $\mathbf{Z}$ & $\mathbf{P}$ & $\mathbf{Q}$ & Effect Size Mean & $\mathbf{\%}$ \%5 Confidence interval Min- Max \\
\hline Fixed Effect & 34 & 17,597 & 0,000 & 202,743 & 0,379 & $0,337-0,421$ \\
\hline Random Effect & 34 & 6,331 & 0,00 & & 0,347 & $0,240-0,455$ \\
\hline
\end{tabular}

the entry grade of the department where they study from the moderator variables will be presented. In the last section, analyzes will be made according to geographical regions of the universities.

When the geographic regions of the province where the universities were studied, most of the study was done in Marmara and Eastern Anatolia regions (20\%) (see Table 2). The least study was conducted in the Southeast Anatolia region. In the distribution according to the score types of the departments, the most studies were carried out in different types of points, and then in the Equilibrium points (such as classroom teaching). The least study was conducted in verbal score types (Turkish Language Teaching). When we examine the years of publications, it is seen that the publications decreased compared to the years. The number of publications available in 2015 is three.

In the classification of effect size of publications, it was found to be 13 small "with $38.2 \%$ and then 9 publications unimportant level, 8 publication moderate level and 3 publictions large level. There are 1 publication with superb. The majority of the studies have a minor and small effect size.

For the general effect calculation, the heterogeneity test for the selection of the model to be used was calculated as 202.743 and the p-value was calculated as 0.00 . The random effect model was used because the value of 33 degrees of freedom and 95\% significance level was greater than $\mathrm{Q}$ value in the chi-square value range table. The overall effect size was calculated as .323 within the limits of 0.240 and 0.455 . Accordingly, when we evaluated in general, a meaningful result in favor of girls. In other words, it can be said that girls' attitudes towards teaching profession are higher than males.

According to the $\mathrm{Z}$ test performed to determine the significance of the Hedges $\mathrm{g}$ values calculated according to the random effect model, it can be said that the difference in effect size was significant since $\mathrm{p}<0.05$ was found in 19 studies (Baykara Pehlivan, 2010; Pektaş and Kamer, 2011; Tümkaya, 2011; Aydın and Sağlam, 2012; Gökçe and Sezer, 2012; Gür Erdoğan and Zafer Güneş, 2012; Kızıltaş et al., 2012; Aydın and Tekneci, 2013; Çağlar, 2013; İpek et al., 2015; Karatekin et al., 2015; İlter and Köksalan, 2011; Uğurlu and Polat, 2011), but because it was p> 


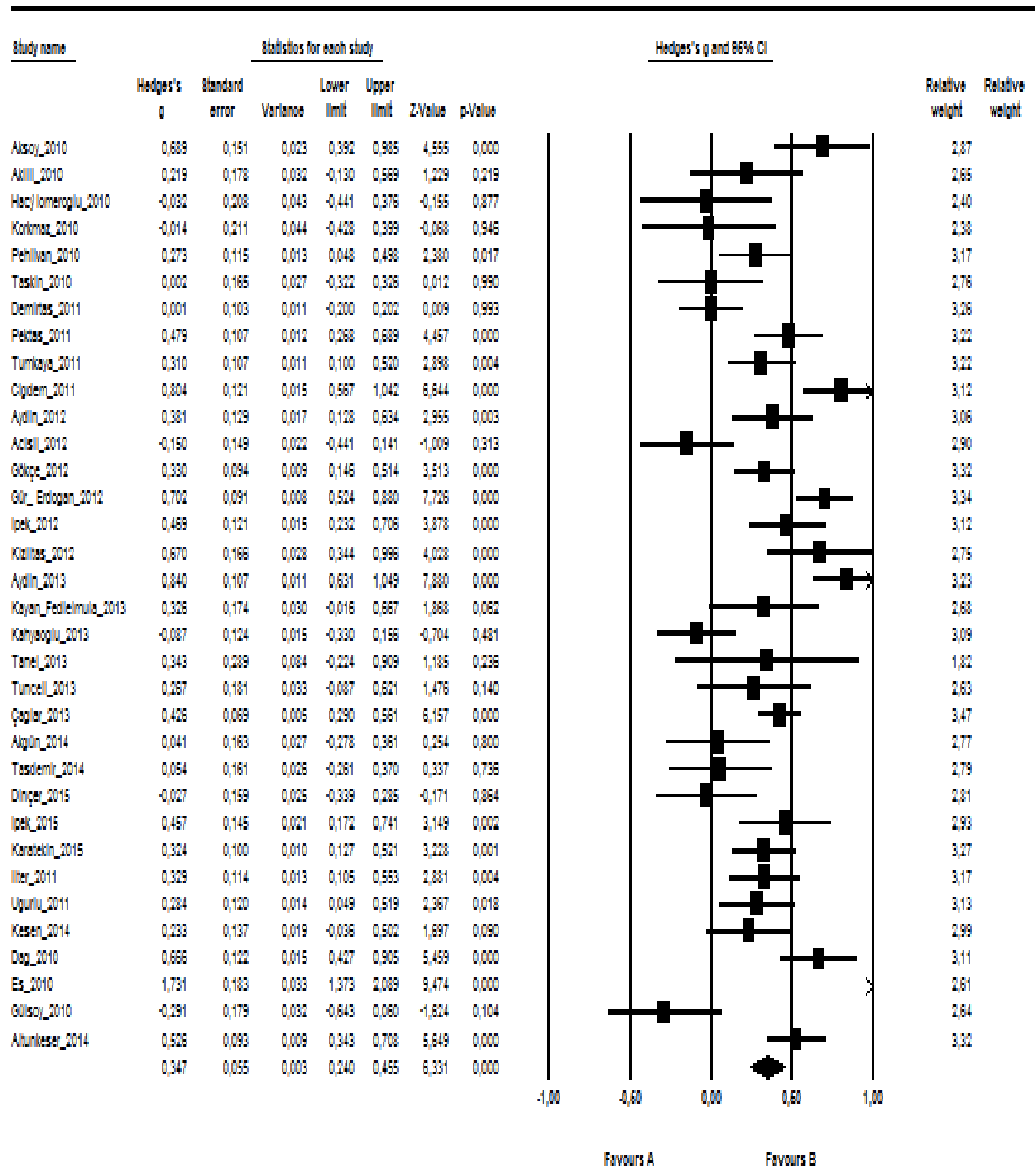

Figure 3. Meta-analysis Diagram of the Effect of Studies (Forest Plot)

0.05 in 15 publications (Hacıömeroglu and Şahin Taşkın 2010; Korkmaz and Usta, 2010; Şahin Taşkın, 2010; Kayan-Fadlelmula, 2013; Kahyaoğlu et al., 2013; Tanel and Tanel, 2013; Tunçeli, 2013; Akgün and Özgür, 2014; Taşdemir, 2014; Dinçer and Yllmaz, 2015; Kesen and Polat, 2014), it was not statistically significant. The z-test calculations performed to determine the statistical significance of the effect size in the random effect model were found to be $z=6,336$ and $p=0,000$. According to this result, meta-analysis results are statistically significant. When we look at the weight of the publications on the impact value of the Kuzlltass et al. (2012) publication with $3.75 \%$ of the highest impact, while the most impact of 1.79\% was the publication of Tanel and Tanel (2013).

In order to determine the joint effect size of the publications in each group, it was determined that the $Q$ values were greater than the critical value and the $\mathrm{p}$ values were less than 0.05 (Table 5). In this respect, it was decided to analyze each subgroup according to the random effect model. When grouping by score types, there are 9 publications in the numerical group and the overall effect size of these publications is calculated as 0.171 . Z $(1,438)$ and $p(0,151)$ values were calculated for the significance of the effect size. According to these results, it can be said that gender has no effect on attitudes towards teaching. However, the effect value was 0.488 and $z(2,513)$ and $p$ $(0,012)$, respectively. Similarly, the effect size was 0.531 and 0.280 , respectively. The effect size value was significant 
Pedagogical Research, 4(1), em0027

Table 5. Results of the Analysis of Teacher Candidates According to Score Types

\begin{tabular}{lccccccc}
\hline Score types & $\begin{array}{c}\text { Publication } \\
\text { Number }\end{array}$ & $\begin{array}{c}\text { Effect } \\
\text { Model }\end{array}$ & $\begin{array}{c}\text { Average Effect } \\
\text { Size }\end{array}$ & $\begin{array}{c}\text { \%95 Confidence } \\
\text { Interval }\end{array}$ & Z Value & P Value & Classification \\
\hline Math-Sciences & 9 & RE & 0,129 & $-0,047-0,304$ & 1,438 & 0,151 & - \\
\hline Social Sciences & 3 & RE & 0,488 & $0,107-0,870$ & 2,513 & 0,012 & Moderate \\
\hline Math-Turkish & 11 & RE & 0,544 & $0,329-0,759$ & 4,966 & 0,000 & Moderate \\
\hline Mixed & 11 & RE & 0,281 & $0,122-0,439$ & 3,476 & 0,001 & Small \\
\hline
\end{tabular}

Table 6. Analysis Results by Geographical Regions

\begin{tabular}{lccccccc}
\hline Region & Publication & Model & $\begin{array}{c}\text { Effect Size } \\
\text { Meab }\end{array}$ & $\begin{array}{c}\text { \%95 Confidence } \\
\text { Interval }\end{array}$ & Z Value & $\begin{array}{c}\text { P Value } \\
\text { Classification of } \\
\text { effect size }\end{array}$ \\
\hline Mediterranean & 3 & SE & 0,337 & $0,191-0,843$ & 4,520 & 0,000 & Small \\
\hline Eastern Anatolia & 7 & RE & 0,190 & $0,011-0,369$ & 2,085 & 0,037 & Small \\
\hline Aegean & 4 & RE & 0,320 & $0,008-0,633$ & 2,008 & 0,045 & Small \\
\hline Southeastern Anatolia & 1 & SE & 0,426 & $0,290-0,561$ & 6,157 & 0,000 & Moderate \\
\hline Central Anatolia & 5 & RE & 0,555 & $0,114-0,996$ & 2,468 & 0,014 & Moderate \\
\hline Black Sea & 5 & RE & 0,458 & $0,147-0,769$ & 2,887 & 0,004 & Moderate \\
\hline Marmara & 7 & RE & 0,167 & $-0,101-0,434$ & 1,222 & 0,222 & Moderate \\
\hline Mixed & 2 & RE & 0,679 & $0,371-0,986$ & 4,325 & 0,000 & M \\
\hline
\end{tabular}

because of $\mathrm{p}<0.05$ for both groups. Verbal, Equal weight score types and programs that accept students with higher attitudes towards teaching girls can be said to be higher. In these groups, the effect values are moderate. In the mixed studies, it was concluded that female students' attitudes were more positive than male students. This situation also overlaps with the general evaluation. The difference between $\mathrm{Qb}(9,598 \mathrm{df} 3)$ and $\mathrm{p}(0,02<0,05)$ values was significant in order to determine the significance of the effect size difference between the types of points. That is, the numerical group differs from the others.

In order to examine the moderating effect of the regions, heterogeneity test was firstly examined, while in the Mediterranean and Southeastern Anatolia regions a constant impact model was preferred due to $\mathrm{p}>0.05$. In other regions and mixed research, calculations were made according to random effect model. The total effect size of the 3 publications in the Mediterranean region was calculated as .337 and $p<0.05$ because it was found that the attitudes of female students towards teaching were higher in the samples in the Mediterranean region than in men. 7 publications were made in Eastern Anatolia. The effect size was calculated as 0.190 and p $<0.05$. The effect size calculation was statistically significant. Similarly, the calculated average effect size values of the regions are at a level of significance as they are calculated as p <0.05 in Aegean, Southeastern Anatolia, Central Anatolia, Black Sea and more than one region (Mixed). However, since it was calculated as $\mathrm{p}>0.05$ in the Marmara region, it was determined that the differentiation of 7 studies in this region was not statistically significant. In other words, it can be said that gender has no effect on teacher attitudes in the studies conducted in Marmara region. In the comparison of regions, $\mathrm{Qb}(11,798 \mathrm{df}=7)$ and $\mathrm{p}(0,11>0,05)$ were calculated as the difference between regions is not statistically significant.

\section{RESULTS}

The most publications were made in Marmara and Eastern Anatolia regions. The least number of publications were made in Southeastern Anatolia. Even when working in mixed considered to be made in a maximum of two geographical regions of Turkey are needed to make the overall operation. When examined according to regions, it can be assumed that the attitudes of female and male teacher candidates in the Marmara region are the same. In other regions, there is a significance in favor of girls. There is no differentiation according to the geographical regions where the studies are conducted.

Most of the study was conducted with Equal Weight Score in the field programs and the least in the verbal programs. When studies on programs that accept students in different types of points are carried out, it is necessary to analyze whether gender has an effect on the attitude, not only on the basis of the programs, but on the basis of the programs.

According to years, the number of studies is decreasing. Considering the change of social structure, studies should be continued in order to determine whether the teacher candidates' attitudes change or not, and also longitudinal studies are needed. In addition, it can be done that the teacher candidates' attitudes changed after they started teaching.

The majority of publications have a small impact level. The average effect size is 0.3323 and has a small effect level. In studies included in the analysis, the effect size in significant studies in favor of girls or boys will be calculated and included in publications and will help researchers in future studies and meta-analysis studies. 
It is significant that teacher candidates differ according to the types of programs they study. The attitudes of female and male students do not differ in the programs that accept students according to the numerical score type. Semerci and Semerci (2004), Turkey has also reached the conclusion that the teachers change in his work on the physical education teachers across the division by gender attitudes. Çapri and Çelikkaleli (2008) In his study at Mersin University, gender was found to be significant in girls' favor and the effect size was moderate. This study coincides with the results. In a meta-analysis study conducted by Kubiatko and Arik (2014) on the theses made after 2001, it was determined that gender had a significant difference in favor of girls and the mean effect size was small.

This study was conducted with prospective teachers in Turkey. In different countries it can be studied to determine whether there are similarities with other countries. In addition, the study may be repeated after a certain time to determine if there is a change in the attitudes of the prospective teacher candidates over time. Another point is that meta-analysis can be done by finding sufficient studies for other groups (Science and Art Faculty and Pedagogical Courses students) not included in the study.

\section{REFERENCES}

* The publications were included in the meta-analysis study.

*Açışlı, S. and Kolomuş, A. (2012). Sınıf Öğretmeni Adaylarının Öğretmenlik Mesleğine Yönelik Tutumlarının İncelenmesi. Ë̆gitim ve Öğretim Arastrmalar Dergisi, 1(2), 266-271.

Akbulut, Ö. E. and Karakuş, F. (2011). The investigation of secondary school science and mathematics pre-service teachers' attitudes towards teaching profession. Educational Research and Reviens, 6(6), 489-496.

*Akgün, F. and Özgür, H. (2014). Bilişim Teknolojileri Öğretmen Adaylarının Öğretmenlik Mesleğine İlişkin Tutumları İle Mesleki Kaygilarının İncelenmesi. Eğitimde Kuram ve Uygulama, 10(5), 1206-1223.

Akpınar, E., Yıldız, E. and Ergin, Ö. (2006). Fen Bilgisi Öğretmen Adaylarının Öğretmenlik Mesleğine Yönelik tutumları. Dokuz Eulül Buca Ë̆itim Fakültesi Dergisi, 19, 56-62.

*Altunkeser, F. (2014). Sınıf Öğretmeni Adaylarının Öğretmenlik Mesleğine İlişkin Tutumlarının Çeşitli Değişkenler Açısından Yordanması. Yayımlanmamıs Yülksek Lisans Teři, Niğde Üniversitesi. Eğitim Bilimleri Enstitüsü.

Andronache, D., Bocoş, M., Boçoş, V. and Macri, C. (2014). Attitudes towards teaching professin. Procedia Social and Behivioral Sciences, 142, 628-632. https://doi.org/10.1016/j.sbspro.2014.07.677

*Aydın, A. and Tekneci, E. (2013). Zihin Engelliler Öğretmenliği Öğrencilerinin Öğretmenlik Mesleğine Yönelik Tutumlar1 İle Kayg1 Düzeyleri. Pegem Eğitim ve Ögretim Dergisi, 3(2), 1-12. https:/ / doi.org/10.14527/V3N2M1

Aydın, A., Sarıer, Y. and Uysal, Ş. (2011). Öğretmenlerin Örgütsel Bağlllıklarında Cinsiyetin Etkisi: Meta Analitik Bir Analiz. Kuram ve Uygulamada Eğitim Bilimleri, 11(2), 615-633.

*Aydın, R. and Sağlam, G. (2012). Öğretmen Adaylarının Öğretmenlik Mesleğine Yönelik Tutumlarının Belirlenmesi. Türk Eğitim Bilimleri Dergisi, 10(2), 257-294.

Baykara Pehlivan, K. (2008). Sınıf Öğretmeni Adaylarının Sosyo-kuiltürel Özellikleri ve Öğretmenlik Mesleğine Yönelik Tutumları Üzerine Bir Çalışma. Mersin Üniversitesi Ë̆gitim Fakuiltesi Dergisi, 4(2), 151-168.

*Baykara Pehlivan, K. (2010). Öğretmen Adaylarının Öğrenme Stilleri ve Öğretmenlik Mesleğine Yönelik Tutumalr1 Üzerine Bir Çalışma. İlköğretim Online, 9(2), 749-763.

Borenstein, M., Hedges, L., Higgins, J. and Rothstein, H. (2009). Introductionto Meta-Analysis. Cornwall, UK: A John Wiley and Sons Ltd. https:// doi.org/10.1002/9780470743386

Bozdoğan, A., Aydın, D. and Yıldırım, K. (2007). Öğretmen Adaylarının Öğretmenlik Mesleğine İlişkin Tutumları. Abi Evran Üniversitesi Kurş̧ehir Ë̈itim Fakültesi Dergisi (KEFAD), 8(2), 83-97.

Can, Ş. (2010, Bahar). Tezsiz Yüksek Lisans Öğrencilerinin Öğretmenlik Mesleğine Yönelik Tutumları. Muğla Üniversitesi Sosyal Bilimler Dergisi, 24, 13-28.

*Çağlar, C.. (2013). Eğitim Fakultesi Öğrencilerinin Yabancılaşma Düzeyleri İle Öğretmenlik Mesleğine Yönelik Tutumları Arasındaki İlişki. Kuram ve Uygulamada Eğitim Bilimleri, 1497-1513.

Çapa, Y. and Çil, N. (2000). Öğretmen Adaylarının Öğretmenlik Mesleğine Yönelik Tutumlarının Farklı Değişkenler Açısından İncelenmesi. Hacettepe Üniversitesi Ĕgitim Fakültesi Dergisi, 18, 69-73.

Çapri, B. and Çelikkaleli, Ö. (2008). Öğretmen Adaylarının Öğretmenliğe İlişkin tutum ve Mesleki Yeterlik İnançlarının Cinsiyet, Program ve Fakültelerine Göre İncelenmesi. İnönü Üniversitesi Eğitim Fakuiltesi Dergisi, 9(15), 33-53.

Çetinkaya, Z. (2009). Türkçe Öğretmen Adaylarının Öğretmenlik Mesleğine İlişkin tutumlarının Belirlenmesi. Elementary Education Online, 8(2), 298-305.

*Dinçer, B. and Yılmaz, S. (2015). İlköğretim Matematik Öğretmen Adaylarının Mesleğe Karşı Tutum ve Umutsuzluk Düzeylerinin İncelenmesi. Turkish International Journal of Special Education and Guidance \& Counseling, 4(1), 35-46. 
Doğan, T. and Çoban, A. (2009). Eğitim Fakuiltesi Öğrencilerinin Öğretmenlik Mesleğine Yönelik Tutumları ile Kayg1 Düzeyleri Arasındaki İlişkinin İncelenmesi. Eğitim ve Bilim, 34(153), 157-168.

Duatepe, A. and Akkuş-Çıkla, O. (2004). The attitudes towards teaching professions of in-service and Pre-service Primary School Teacher. Pedagogika, 70, 61-65.

Ellis, P. (2010). The Essential Guide to Effect Sizes Statistical Power, Meta-Analysis, and the Interpretation of Research Results. Cambridge, UK: Cambridge University Press. https://doi.org/10.1017/CBO9780511761676

Eraslan, L. and Çakıcı, D. (2011, Mayıs). Pedagojik Formasyon Programı Öğrencilerinin Öğretmenlik Mesleğine Yönelik Tutumları. Kastamonu Ë̆itim Dergisi, 19(2), 427-438.

Furlong, J., Cochran-Smith, M. and Bernnan, M. (2009). Policy and Politics in Teacher Education: International Perspectives. New York, USA: Routledge.

*Gökçe, F. and Sezer, G. (2012). Öğretmen Adaylarının Öğretmenlik Mesleğine Yönelik Tutumları (Uludağ Üniversitesi Örneği). Uludağ Üniversitesi Eğitim Fakuiltesi Dergisi, 25(1), 1-23.

Güneyli, A. and Aslan, C. (2009). Evaluation of Turkish prospective teachers' attitudes towards teaching profession (Near East University case). Procedia Social and Behavioral Sciences, 1, 313-319. https://doi.org/10.1016/j.sbspro.2009.01.059

*Gür Erdoğan, D. and Zafer Güneş, D. (2012). Sakarya Üniversitesi Eğitim Fakuiltesi Birinci Sınıf Öğrencilerinin Öğretmenlik Mesleğine Karşı Tutumları. Uludağ Üniversitesi Eğitim Fakiiltesi Dergisi, 25(1), 51-62.

Gürbüz, H. and Kışoğlu, M. (2007). Tezsiz Yüksek Lisans Programına Devam Eden Fen-Edebiyat ve Eğitim Fakültesi Öğrencilerinin Öğretmenlik Mesleğine Yönelik Tutumları (Atatürk Üniversitesi Örneği). Eræìncan Ë̈itim Fakültesi Dergisi, 9(2), 71-83.

*Hacıömeroğlu, G. and Şahin Taşkın, Ç. (2010). Fen Bilgisi Öğretmenliği ve Ortaöğretim Fen ve Matematik Alanları (OFMA) Eğitimi bölümü Öğretmen Adaylarının Öğretmenlik Mesleğine İlişkin Tutumları. Ahi Evran Eğitim Fakültesi Dergisi, 11(1), 77-90.

Higgins, J., Thompson, S., Deeks, J. and Altman, D. (2003). Measuring inconsistency in meta-analyses. British Medical Journal, 327, 557-560. https:/ / doi.org/10.1136/bmj.327.7414.557

*ìlter, İ. and Köksalan, B. (2011). Sınıf Öğretmeni Adaylarının Öğretmenlik Mesleğine Olan Tutumları. Frrat Üniversitesi Sosyal Bilimler Dergisi, 21(1), 113-128.

İpek, C. and Camadan, F. (2012). Primary teachers' and primary pre-service teachers' self-efficacy beliefs and attitudes toward teaching profession. International Journal of Human Sciences, 9(2), 1206-1216.

*İpek, C., Kahveci, G. and Camadan, F. (2015). Sınıf Öğretmeni Adaylarının Öğretmenlik Mesleğine Ve Okul Yöneticiliğine Yönelik Tutumları. Kastamonu Ë̈itim Dergisi, 23(1), 211-226.

*Kahyaoğlu, M., Tan, C.. and Kaya, M. (2013). İlköğretim Öğretmen Adaylarının Öğrenme Stilleri Ve Öğretmenlik Mesleğine Yönelik Tutumları. Mustafa Kemal Üniversitesi Sosyal Bilimler EnstitüsüDergisi, 10(1), 225-236.

*Karatekin, K., Merey, Z. and Keçe, M. (2015). Sosyal Bilgiler Öğretmen Adaylarının Öğretmenlik Mesleğine Yönelik Tutumları. YYÜ Eg̈itim Fakeiltesi Dergisi, XII(1), 70-96.

*Kayan Fadlelmula, F. (2013). Attitudes of Pre-service Teachers towards Teaching Profession. Turkish Journal of Education, 2(4), 55-63.

*Kesen, İ. and Polat, M. (2014). Eğitim Fakültesi 4. Sınıf Öğretmen Adaylarının Öğretmenlik Mesleğine İlişkin Tutumları: Muş Alparslan Üniversitesi Örneği. Ë̆itimde Kuram ve Uygulama, 10(2), 556-578.

*Kızıltaş, E., Halmatov, M. and Sarıçam, H. (2012). Okul Öncesi Öğretmenliği Öğrencilerinin Öğretmenlik Mesleğine Yönelik Tutumlar1 (Ağr1 İbrahim Çeçen Üniversitesi Örneği). Mehmet Akif Ersoy Üniversitesi Eğitim Fakiltesi Dergisi, 12(23), 173-189.

*Korkmaz, Ö. and Usta, E. (2010, Aralık). Öğretmen Adaylarının Öğretmenlik Mesleğine Karşı Tutumları ile Algıladıkları Etkileşim-İzleme Kaygıları ve Problem Çözme Becerileri Arasındaki İlişki. Türkiye Sosyal Arastirmalar Dergisi, 1-22.

Kubiatko, M. and Arik, S. (2014). Comparison of the Effects of Gender Variable on Attitudes towards the Teaching Profession by Random and Fixed Effects Model: Meta-Analysis. Educational Process: International Journal, 3(1-2), 52-64. https://doi.org/10.12973/edupij.2014.312.4

Littell, J., Corcoran, J. and Pillai, V. (2008). Systematic Reviews and Meta-Analysis. Oxford, UK: Oxford Universty Press. https://doi.org/10.1093/acprof:oso/9780195326543.001.0001

Özyurt, Y. and Eren, A. (2014). Fen Bilgisi Öğretmen Adaylarının Öğretmenlik Mesleğine ve Kopya Çekmeye Yönelik Tutumlarının Görünümü. Bartm Üniversitesi Eğitim Fakültesi Dergisi, 3(1), 78-101. https://doi.org/10.14686/BUEFAD.201416208

Pektaş, M. and Kamer, S. (2011). Fen Bilgisi Öğretmen Adaylarının Öğretmenlik Mesleğine Yönelik Tutumları. Türk Eğitim Bilimleri Dergisi, 9(4), 829-850.

Polat, Ü. and Kaysıli, A. and Aydın, Ş. (2015). Öğretmen Adaylarının Eğitimsel, Toplumsal Ve Siyasal Beklentileri Üzerine Bir Araştırma. Cumburiyet International Journal of Education-CIJE e-ISSN: 2147-1606, 4(2), 2015, 1-14. 
Rosenthal, R. and DiMatteo, M. (2001). Meta-Analysis: Recent Developments in QuantitativeMethods for Literature Reviews. Annual Reveview of Psychology, 52(1), 59-82. https:/ / doi.org/10.1146/annurev.psych.52.1.59

Semerci, N. ve Semerci, Ç. (2004). Türkiye'de Öğretmenlik Tutumları. Frrat Üniversitesi Sosyal Bilimler Dergisi, 14(1), 137-146.

Şahin Taşkın, Ç. and Hacı̈meroğlu, G. (2010). İlköğretim Bölümü*Öğretmen Adaylarının Mesleğe Yönelik Tutumları: Nicel ve Nitel Verilere Dayalı Bir İnceleme. İlkëgretim Online, 9(3), 922-933.

*Tanel, Z. and Tanel, R. (2013).Öğretmenlik Mesleğine Yönelik Tutumlarının İncelenmesine İlişkin Boylamsal Bir Çalışma. Amasya Üniversitesi Eğitim Fakeiltesi Dergisi, 2(2), 451-468.

*Taşdemir, C. (2014). İlköğretim Matematik Öğretmen Adaylarının Öğretmenlik Mesleğine Yönelik Tutumlarının İncelenmesi. Bilgisayar ve Eğitim Arasttrmalar Dergisi, 2(3), 91-114.

Temizkan, M. (2008). Türkçe Öğretmeni Adaylarının Öğretmenlik Mesleğine Yönelik Tutumalrı Üzerine Bir Araştırma. Türk Eğitim Bilimleri Dergisi, 6(3), 461-486.

Tok, Ş. (2011, February). Pre-sevice Primary Education Teachers' Changing Attudes Towords Teaching: a Longitudinal Study. European Journal of Teacher Education, 34(1), 81-97. https://doi.org/10.1080/02619768.2010.534130

*Tunçeli, H. (2013). Öğretmen Adaylarının İletişim Becerileri İle Öğretmenlik Mesleğine Yönelik Tutumları Arasındaki İlişkinin İncelenmesi (Sakarya Üniversitesi Örneği). Pegem Eğitim ve Ögrretim Dergisi, 3(3), 51-58. https://doi.org/10.14527/C3S3M5

*Tümkaya, S. (2011). Sınıf Öğretmenliği Öğrencilerinin İletişim Becerileri ile Öğretmenlik Tutumlarının İncelenmesi. C.. Ü. Sosyal Bilimler Enstitïsï Dergisi, 20(2), 49-62.

*Uğurlu, C. T. and Polat, S. (2011). Sınıf Öğretmenliği Öğrencilerinin Öğretmenlik Mesleğine İlişkin Tutumları. CU Sosyal Bilimler Dergisi, 35(1), 68-74.

Üstün, U. and Eryllmaz, A. (2014). A Reseach Methodology to Conduct Effective Syntheses: Meta-Analysis. Education and Science, 39(174), 1-32.

Üstüner, M., Demirtaş, H. and Cömert, M. (2009). The Attitudes of Prospective Teacher towards the Profession Teaching. Eğitim ve Bilim, 34(151), 140-155.

Yaman, E., Yaman, H. and Eskicumalı, A. (2001). Öğretmenlik Mesleğinin Sosyo-Ekonomik Statüsü/Bu Mesleğin Bir Bayan Mesleği Haline Dönüşmesi Durumu ve Eğitim Fakultesi Üzerine Bir Araştırma. Sakarya Üniversitesi Ë̆itim Fakültesi Dergisi, 2(1), 53-68. 